\title{
Biodiversity Conservation and Land Rights in South Africa: Whither the Farm Dwellers?
}

\author{
Wendy Crane
}

Assignment presented in partial fulfillment of the requirements for the degree MPhil

Sustainable Development, Planning and Management at the University of Stellenbosch

Supervisor: Mark Swilling

April 2006 


\section{Declaration}

I, the undersigned, hereby declare that the work contained in this assignment is my own original work and that I have not previously in the intirety or in part submitted it at any university for a degree.

Signature

Date. 


\section{BIODIVERSITEIT-BEWARING EN GRONDREGTE IN SUID-AFRIKA: PLAASBEWONERS WAARHEEN?}

\section{Opsomming}

Suid-Afrika is uniek in dié sin dat sy belangwekkende globale diversiteit, wat op groot skaal bedreig word, ' $\mathrm{n}$ medebestaan voer met ' $\mathrm{n}$ apartheidsgeskiedenis van onteiening wat ' $n$ skreiende ongelyke grondeienaarskap-patroon en wydverspreide landelike armoede tot gevolg gehad het. Dit is in dié konteks dat die na-apartheid regering sy konstitisionele en internasionale verpligtinge moet vervul om sy omgewingsbates te beskerm en ook grondhervorming moet onderneem wat voorheen onteiendes tot voordeel sal strek. Gevolglik is daar voortdurend ' $\mathrm{n}$ stryd van versoenende, komplekse en dikwels kontrasterende verhoudings tussen armoede, onregverdige toegang tot hulpbronne en die beskerming van biodiversiteit. Huidige pogings om die Kaapse Blommeryk te bewaar, beklemtoon vennootskappe tussen private grondeienaars en bestaande natuurreservate om volhoubare gebruik van biodiversiteit te bevorder. Hierdie studie ondersoek die potensiële impak van dié benadering op plaasbewoners en hoe veranderende grondgebruik hulle lewensbestaan en besitreg op grond mag beïnvloed. Primêre navorsing is in Baviaanskloof gedoen waar dié model in ' $n$ vroeë fase van implementering is. Hierdie studie identifiseer sistemiese en strukturele spanning rondom huidige pogings om biodiversiteit-bewaring en die belange van plaaswerkers te versoen. Dit dokumenteer ook anngeleenthede rakende proses en beginsel wat in die toekoms belangrik kan blyk te wees. Sodoende word aandag gevestig op die invloed van magsverhoudinge op plase en uiters komplekse institusionele reëlings om die ware omvang van die deelname van plaasbewoners, wat geraak word, en die doeltreffendheid van maatskaplike beskermingsbeleid te bepaal. Bevindinge maan ook dat daar nie te veel.staatgemaak moet word op ekotoerisme as vername arbeidsbron nie. Daar word geredeneer dat eerder steun verleen behoort te word aan veelvuldige lewensbestaanstrategieë.

Sleutelwoorde:

Bewaring, biodiversiteit-ekonomie, grondregte, plaasbewoners, Suid-Afrika, Baviaanskloof 


\title{
BIOdiversity CONSERVATION AND LAND RightS IN SOUTH AFRICA: WHITHER THE FARM DWELLERS?
}

\begin{abstract}
South Africa is unique in that its globally significant biodiversity, which is under major threat, coexists with an apartheid history of dispossession that produced a starkly unequal land ownership pattern and widespread rural poverty. It is in this context that the post-apartheid government must fulfil constitutional and international obligations to safeguard environmental assets as well as undertake land reform benefiting the previously dispossessed. Consequently, there is a continuous challenge of reconciling complex and often conflicting relationships between poverty, inequitable access to resources, and the protection of biodiversity. Current efforts to conserve the Cape Floral Kingdom emphasise partnerships between private landowners and existing nature reserves to promote sustainable utilisation of biodiversity. This paper explores the potential impact of this approach on farm dwellers, and how changing land use may affect their land tenure rights and livelihoods. Primary research was undertaken in the Baviaanskloof, where this model is in an early stage of implementation. The paper identifies systemic and structural tensions in current attempts to reconcile biodiversity conservation and farm dwellers' interests, and documents issues of process and principle that could become important in the future. In doing so, it highlights the influence of on-farm power relations and highly complex institutional arrangements in determining the real extent of participation by affected farm dwellers and the efficacy of social safeguard policies. Findings also caution against an over-reliance on ecotourism as the major occupation and argues instead for support to multiple livelihood strategies.
\end{abstract}

Key words:

Conservation, biodiversity economy, land rights, farm dwellers, South Africa, Baviaanskloof 


\section{BIODIVERSITY CONSERVATION AND LAND Rights IN SOUTH AFrica: WHITHER THE FARM DWELLERS?}

\section{INTRODUCTION}

South Africa is unique in two quite distinct ways. First, it is a country with massive biodiversity. The third most biologically diverse country in the world, it comprises an astonishing variety of biomes including Mediterranean-type, arid, alpine and tropical environments. Within these biomes there is enormous species diversity and endemism (Sandwith, 2002). The country contains between 250000 and 1000000 species, many of which occur nowhere else. In the plant kingdom alone, at least 80 percent of the $18-20000$ species are endemic. It also has the highest known concentration of threatened plants, and the highest extinction estimates anywhere in the world (Wynberg, 2002). It is home to the Cape Floral Kingdom ${ }^{1}$, one of the world's top 25 'biodiversity hotspots' (Myers et al., 2000). Second, South Africa has an extreme history of land dispossession based on racial discrimination. This has produced a highly unequal pattern of land ownership and widespread rural poverty. Following the first democratic elections in 1994, the new postapartheid government introduced a programme of redistributive land reform which seeks to transform the racial pattern of land ownership as well as protect and upgrade the tenure rights of people with insecure rights to land (DLA, 1997). Farm dwellers constitute one of the most important target groups of this last element of the land reform programme. Living and working under insecure tenure arrangements on South Africa's whiteowned farms, farm dwellers - who are almost all black - have long been 
considered the poorest, most underprivileged and disenfranchised of the country's populace. Recent research indicates that land reform to date has yielded little benefit to this marginalised group, despite government policy and intentions (Hall, 2004a; Wegerif \& Russell, 2005). The post-apartheid government faces a major challenge in setting up policy and legislative frameworks that both advance freedom and equality and protect the country's natural resource base.

To fulfil its constitutional obligations to safeguard biodiversity, as well as commitments under regional and international environmental agreements, the state gives due importance to the expansion of conservation estate - both in terms of protected area coverage and outside formal protected areas. Recent years have seen the creation of biodiversity 'mega-reserves' ${ }^{2}$ - large areas under some form of protection, based on the voluntary and cooperative participation of private landowners. Three mega-reserves have been established in the Cape Floral Kingdom Baviaanskloof, Cederberg, Garden Route - as part of the Cape Action for People and Environment programme (C.A.P.E.). ${ }^{3}$ They are conceptualised as partnerships between private land owners and existing nature reserves towards sustainable utilisation of the unique biodiversity in these areas. The focus is on exposing people to more sustainable ways of using the land and natural resources, promote the adoption of conservationconscious farming methods or other land use practices, and where possible to set aside land for formal protection. This approach differs markedly from the 'fences and fines' approach - drawing boundaries, regulating 
entry, and penalising unauthorised use - typical of many conservation efforts throughout the world in the past.

The research described in this article explores the possible impact of this new approach on farm dwellers. Through a case study of the Baviaanskloof Mega-Reserve in Eastern Cape Province, it seeks to build an understanding of how changing land use in response to conservation concerns may affect land tenure rights and livelihoods of farm dwellers living and working on land targeted for inclusion in the mega-reserves. Recent evidence of farm dwellers' continuing vulnerability to evictions and loss of livelihood (Wegerif \& Russell, 2005) gives this question added urgency.

Field research was undertaken in the Baviaanskloof area, and included interviews with 13 landowners and 61 farm dwellers and workers across 15 farms. Another major source of information was a series of indepth interviews with key staff in the Baviaanskloof Mega-Reserve Project Management Unit. Information thus obtained was combined with direct observations, review of many secondary sources including project documents, government policy documents and legislation, and a questionnaire survey of the mega-reserve steering committee.

The next section provides a contextual overview of the broader issues around sustainable development, biodiversity conservation and land rights, as well as how these are linked, from global level to the national experience in South Africa. This is followed by an empirical case study analysis of the Baviaanskloof Mega-Reserve and the specific situation of 
farm dwellers there. A brief conclusion along with lessons for policy and practice completes the article.

\section{BACKGROUND}

\section{Sustainable development}

The problematique of the people-ecology interface is framed against the overall backdrop of sustainable development. This concept is not new but has grown significantly in importance on the international agenda in recent years. Global policy debates increasingly focus on the challenges posed by natural resource limits to the ways in which production and consumption are structured in a world sharply divided between rich and poor.

The meaning of 'sustainability' and 'sustainable development' is hotly contested. Apart from a general recognition that the world is faced with an environmental crisis and that fundamental change is required to overcome it (Mebratu, 1998), the discourse is characterised by varying definitions and interpretations. While consensus on a vague concept rather than disagreement over a sharply defined one - can be a good political strategy (Daly, 1996), the fact that such an elusive concept drives many policy processes at global, regional and national levels is problematic, especially in a world of major power imbalances.

Since the 1970s the debate has shifted from conservation of nature for its own sake, to protection of the productivity of natural resources for economic use - put differently, to the "conservation of growth" (Sachs, 1999:81). When the sustainable development concept first appeared in the 
1980 World Conservation Strategy, it subtly shifted the locus of

sustainability from nature to development. But since development is itself such a loose concept, just what it is that should be sustained is perpetually contested. The formula proposed by the Brundtland Commission (WCED, 1987) was essentially unable to resolve this dilemma, although it did bring into sharper focus the tension between the crisis of justice and the crisis of nature, both in the present and in the future.

In South Africa, given the apartheid legacy of a deeply divided economic structure, policy making for sustainable development must focus on reducing inequality and poverty. The past decade has thus seen environmental issues move squarely into a socio-political arena concerned with human rights, access to natural resources, social justice, equity and sustainability (Wynberg, 2002). The new Constitution guarantees the right to environmental protection so as to "secure ecologically sustainable development and use of natural resources while promoting justifiable economic and social development" (RSA, 1996). However, this commitment generates inherent tensions. Policymakers face the continuous challenge of reconciling complex and often conflicting relationships between poverty, inequitable access to resources, economic growth, and protection of environmental assets.

\section{Biodiversity conservation}

An important proposition in conservation circles is that the world is undergoing unprecedented loss in biological diversity due to increased human activity. Despite significant effort to improve our knowledge base 
with regard to the magnitude and speed of loss (Myers et al., 2000), current estimates of global extinction rates remain diverse and imprecise (Murray, 1995). It is therefore no surprise that there is continuing public scepticism about the degree of environmental crisis and the extent to which it is brought on by human behaviour (Daily, 1999). Tackling the science and information gap is seen as a major priority. Massive growth in certain ecosystem products, notably foods and fibres, has come at the expense of greatly reduced output of many other ecosystem goods and services, such as water quality and quantity, biodiversity and carbon storage (WRI, 2001). In spite of this rapid depletion, ecosystem services remain poorly understood, undervalued and insufficiently monitored, and there are growing calls for greater recognition and improved scientific measurement. Key questions about who benefits from ecosystem use, who pays for its decline, and how to create public and political will to act are now being raised. An important initiative in this regard is the Millennium Ecosystem Assessment (MA, 2005).

Habitat destruction is a leading cause of species extinction (Murray 1995). Protection of habitat is therefore seen as a key factor in slowing down extinction rates. Myers et al. (2000) identified 25 'biodiversity hotspots' around the world, which collectively occupy only 1.4 percent of global land area, but contain the sole remaining habitats of nearly half the Earth's plant species and over one third of its vertebrate species. As these habitats all face high risk of elimination, they put forward a convincing case in favour of tight targeting of conservation support to these areas. Global institutions like the World Bank and United Nations have embraced 
this 'silver bullet' strategy, as evident in their support for South Africa's C.A.P.E. programme aimed at conserving the Cape Floral Kingdom (GEF, 2004).

Agriculture is a key factor in habitat destruction, and hence in loss of biodiversity. In his seminal work on the fates of human societies, Jared Diamond (1997) traces the profound effects of the agricultural revolution, which began about ten thousand years ago. Its impact on biodiversity over the millennia is eclipsed, however, by the rise of large-scale modern agriculture during the $20^{\text {th }}$ century (Pretty, 1995). In South Africa, it is estimated that 31 percent of the Cape Floral Kingdom has been transformed by agriculture and commercial forestry (C.A.P.E., 2000). A key part of the C.A.P.E. strategy is therefore to persuade private land owners to adopt conservation-based farming methods or other land use practices.

Over the past decade the role of multilateral environmental agreements has grown in importance in biodiversity conservation (Steiner et al., 2003). National policy is increasingly formulated on the basis of global concerns. The Convention on Biological Diversity (CBD) requires signatory states to integrate conservation and sustainable use of biodiversity into relevant sectoral plans, programmes and policies. South Africa has made significant strides towards such 'mainstreaming' (Pierce et al., 2002). Environmental protection is a constitutional right; important policy frameworks have been developed, including the National Environmental Management Act (RSA, 1998) and the Biodiversity Act (RSA, 2004). Under its commitment to the CBD, South Africa needs to 
increase the amount of land allocated to formal conservation from less than 6 percent to 10 percent. Considerable progress has been made in this respect, with over 457000 hectares of land added since 1994 - the greatest expansion in any comparable period in the country's conservation history (DEAT, 2003).

But although sustainable development is entrenched in South Africa's legislative and policy framework, socio-economic issues tend to override calls for biodiversity conservation. These include a lack of awareness of the importance of biodiversity to the economy and to sustainability, and agricultural and tax incentives that encourage unsustainable land use practices (C.A.P.E., 2000). Moreover, mainstreaming biodiversity must be seen against the country's social and political history. Patterns of settlement and land use by hunter-gatherers, pastoralists and African farmers were profoundly altered by colonial farmers and traders. Enormous disparities in power and access to land and resources led to a system of racially-defined homelands, farming areas and cities, and a grossly skewed distribution of population and wealth (Sandwith, 2002). This legacy underlies the government's intent to increase conservation's contribution to poverty alleviation and economic development.

\section{The land issue in South Africa}

South Africa's land issue is rooted in a systematic process of racially-based land dispossession that began in 1652 and spanned over four centuries - the colonial era (see Delius, 1983; Elphick \& Malherbe, 1989) 
and subsequent decades of apartheid rule (see Beinart \& Dubow, 1995;

Platzky \& Walker, 1985). When the first democratically elected government came to power in 1994, about 60000 white farmers owned 86 percent of the country's agricultural land, while over 13 million African people survived precariously on the remaining 14 percent (Bernstein, 1996). As white power and privilege has been directly associated with this skewed distribution, land reform is seen by many as imperative to the success of the national transformation project (Hall, 2004b) - a precondition for the legitimacy of the new non-racial order.

The land reform programme is driven by the twin goals of restoring and upgrading land rights, and reducing poverty by promoting rural development. Rural people represent a disproportionate majority of those living below the poverty line: 71 percent of South Africa's poor reside in rural areas (SSA \& UNDP, 2003). The new Constitution provides the framework for land reform and forms the basis of a three-pronged approach: restitution, redistribution, and tenure reform. The aim of restitution is to restore land or provide other redress to those dispossessed of their land since the introduction of the Natives Land Act of 1913. Land redistribution is aimed at transforming the racially skewed pattern of land ownership, through a grant-based programme that assists certain categories of people to acquire land through the market. ${ }^{4}$ Land tenure reform is intended to secure and upgrade the tenure rights of people who occupy but do not own land (DLA, 1997). Whereas land redistribution and restitution involve the transfer of land ownership, tenure reform affects the ways in which people hold land (Hall, 2003). 
In much of Africa, land is relatively evenly distributed under customary tenure systems. Southern Africa differs in that colonial settlers concentrated productive land into large private estates, creating a class of landless people and leading to widespread land-related poverty (Quan, 2000). South Africa represents the most extreme case in this respect (Lahiff, 2003). Tenure reform here is intended to secure and upgrade the tenure rights of people with insecure rights to land as a result of past discriminatory practices. Farm dwellers are an important category: nearly one million are employed and about three million reside on commercial farms, in insecure circumstances on land belonging to other people (Hall, 2004a). They are among the poorest and most marginalised people in South Africa - a rural proletariat in a political economy featuring large concentrations of land owned by white commercial farmers and worked by black farm dwellers, in relationships often characterised by disempowerment and racial paternalism (Du Toit, 1996). Poorly paid, geographically isolated and politically marginalised, their plight has been further exacerbated by deregulation in the agricultural sector post-1994, which has led to job losses, casualisation and evictions (CRLS, 2003). The Extension of Security of Tenure Act of 1997 (ESTA) was enacted to secure farm dwellers' tenure rights and to prevent arbitrary evictions. It does not stop evictions but regulates when and how they can happen. But ESTA has been notoriously difficult to enforce. Monitoring compliance is a major challenge, and data on evictions - legal and illegal is very imprecise (Hall, 2004a). A recent survey suggests that close to 1 million farm dwellers have been evicted since 1994 - more than in the 
preceding decade - and that just 1 percent involved a legal process (Wegerif \& Russell, 2005). Improved law enforcement is no solution: it cannot secure long-term independent tenure rights for farm dwellers, unless it is linked to viable options of acquiring and transferring land. In recognition of these shortcomings a new farm tenure law is under preparation, but the state faces a fundamental dilemma in the extent to which farm dwellers' tenure can be secured without dispossessing land owners of their property rights (Hall, 2004a).

\section{The nexus of biodiversity conservation, land rights and poverty}

The relationship between biodiversity conservation and poverty eradication is heavily contested. Some lament that the fight against poverty has put conservation on the defensive, arguing that protected areas are being treated as "scapegoats for failed models of economic development" (Sanderson \& Redford, 2004:146). Others point at evidence that protected area policies bring significant costs for the poor (Brockington \& SchmidtSoltau, 2004), and suggest that conservation agencies are partly to blame for not bringing biodiversity into mainstream poverty reduction efforts (Roe \& Elliott, 2004). Around the world, the creation of protected areas has often resulted in the alienation of indigenous populations from their land and resources. Where conservation has come into conflict with land rights, approaches to reconcile the two objectives have varied widely depending on the local context and on the nature of the communities involved - agricultural or pastoralist, rural or urban, poor or middle-class, etc. (Kepe et al., 2005). 
In South Africa, much has been written about biodiversity conservation, especially in light of post-apartheid policy changes, and the same holds for land reform. But there has been little analysis of the two sectors combined or the dynamics between them. The relationship is historically characterised by mistrust because of past race-based policies. During and even prior to apartheid, the establishment of protected areas was often accompanied by land dispossession and forced removals of black people residing there. Today, conservation is still widely associated with protected areas that serve a privileged elite - albeit no longer exclusively white - holding little relevance to the majority of South Africans (Wynberg, 2002).

Where studies have explored both issues, the focus has tended to be on well-publicised land restitution claims in famous national parks such as the Makuleke community in the Kruger National Park (De Villiers, 1999), and the Khomani San in the Kalahari Gemsbok National Park. Other, less well-known protected areas have received relatively little attention - the case of Mkambati Nature Reserve in the Eastern Cape is an exception to the rule (Kepe, 2004). Moreover, these studies have invariably focused on formal protected areas, rather than on how conservation efforts on private land holdings outside protected areas affect tenure rights of poor people residing there. The present study is an attempt to address this imbalance.

These cases illustrate the challenge the state faces in reconciling land reform with conservation policies on the one hand and the need to tackle poverty in the country's rural areas on the other. The Baviaanskloof 
Mega-Reserve offers a glimpse into how these different agendas might coalesce.

\section{BIODIVERSITY CONSERVATION AND FARM DWELLERS IN THE}

\section{BaviaAnskloof: A Case Study}

\section{Description of the area}

The Baviaanskloof, or "Valley of Baboons", is situated in the western part of South Africa's Eastern Cape Province (see Figure 1). It is a $75 \mathrm{~km}$ long valley of varying width and depth, and lies between two parallel east-west running mountain ranges: the Baviaanskloof Mountains in the north and the Kouga Mountains in the south. The eastern-most point of the valley is about $95 \mathrm{kms}$ north-west of the coastal city of Port Elizabeth, and its most southerly point is $50 \mathrm{kms}$ from the Indian Ocean.

\section{[ Figure 1]}

The wider Baviaanskloof area is one of outstanding natural beauty and biodiversity, and an important water catchment. No fewer than seven of South Africa's eight biomes are represented there - the Fynbos, Subtropical Thicket, Nama-karroo, Succulent Karoo, Grassland, Savanna and Forest biomes (Boshoff, 2005). It supports a high diversity of species, several of which are Red Data listed - including leopard (Panthera pardus), Cape mountain zebra (Equus zebra zebra), and grey rhebok (Pelea capreolus) (Clark, 1998). It is at the convergence of two of the 
world's top 25 biodiversity hotspots: the Cape Floristic Region and the Succulent Karoo (Myers et al., 2000). This natural treasure has led to part of the area being declared a World Heritage Site, along with seven other reserves in the Cape Floristic Region.

The surrounding area is facing growing socio-economic pressures. The local economy is based almost entirely on agriculture, involving a mix of pastoralism and irrigated crops. Commercial agriculture is operating at or near to capacity and there is limited space for growth. An overall decline in the regional economy has been accompanied by a general depopulation. Agriculture is unlikely to provide the economic boost required to address growing unemployment. Conservation-based tourism has been advocated as an alternative and sustainable form of land use with the potential to contribute to the local and regional economy (Boshoff $e t$ al., 2000).

While much of the Baviaanskloof is state-owned, in the western part of the valley some 50000 ha remains under private ownership. About 20 commercial farms here are entirely surrounded by protected area. Vegetable seed production, once a thriving industry with significant labour demand, has declined substantially following the cessation of farming subsidies and introduction of agricultural labour legislation. This has led to the loss of many permanent and casual jobs since 1994. Most farmers now practice mixed small stock farming, which is much less labour-intensive. Pensioners, farm workers and their extended families make up over 70 percent of the valley's community (Boshoff et al., 2000). Many depend 
entirely on government pensions and disability grants. The population currently stands at around 1000 and has been on the decline.

\section{A conservation history}

Conservation in the Baviaanskloof goes back to 1923 when stateowned land in the area was proclaimed as a forest reserve and water catchment zone. Purchase by expropriation of key properties in the 1970s led to the consolidation of a provincial nature reserve system, a cluster of protected areas of which the Baviaanskloof Nature Reserve is the focal point. During the 1980s the particular importance of the Baviaanskloof Nature Reserve for biodiversity conservation and for the provision of essential ecosystem services (especially water) became more widely recognised. Additional land purchases increased the size of the reserve to about 175000 ha by the turn of the century (Boshoff et al., 2000). Further expansion of the protected area is continuing up to the present.

The long and convoluted boundary makes management of the conservation estate expensive. Due to its shape, the present protected area is exceptionally vulnerable to the 'edge effect' and the potential for conflicts with neighbouring land owners is high in terms of fire risk, predator poaching, alien vegetation, soil erosion, water wastage etc. This situation led to a proposal in 1997 to consolidate the western sector of the reserve through compulsory acquisition of all private land inside the Baviaanskloof (Clark, 1998). While this could yield many benefits, the proposal failed to appreciate socio-political realities of the new South Africa and that the future of the reserve as a viable conservation area must 
take into account human communities and land use on properties adjacent to the reserve. The proposition that inhabitants simply be relocated to the nearby town of Willowmore met with fierce resistance from all sides of the Baviaanskloof community (Roodt, 2003) and was clearly no longer viable under the new democratic order. The essence of the proposal, however, was later taken up by C.A.P.E. when it identified the Baviaanskloof Nature Reserve and adjacent areas as a potential mega-conservation areaculminating in the present Baviaanskloof Mega-Reserve Project. Its underlying philosophy of "keeping people on the land in living landscapes" (BMRP, 2004a) differs radically from the previous concept. Nevertheless, a legacy of expropriation in earlier decades and resettlement issues arising from more recent land acquisitions, coupled with anxieties and mistrust generated by the 1997 proposal, pose a major challenge to the new strategy.

\section{The Baviaanskloof Mega-Reserve Project (BMRP)}

The BMRP is conceived as a 20 -year process to conserve the area's biodiversity, protect its critical role as a regional water provider, and deliver economic benefits to surrounding communities. According to project documents (BMRP, 2004a; GEF, 2004) it will stimulate a 'biodiversity economy' ${ }^{5}$ by promoting alternative productive land uses notably though not exclusively ecotourism. Under the auspices of the Provincial Department of Economic Affairs, Environment and Tourism (DEAET), a Project Management Unit (PMU) was created in 2003 to manage the initial phase of this process. ${ }^{6}$ 
Expansion of the reserve can involve land purchase by government but is primarily directed towards voluntary inclusion of private land through the use of formal agreements with landowners (BMRP, 2004b). This expansion does not necessarily exclude the people residing there. It is the express intent of the BMRP that no people should be involuntarily displaced, and that where relocation is proposed it will only be done in a consensual manner. In such an event, the BMRP is bound by a Resettlement Policy Framework and Process Framework (RPF/PF) designed to comply with World Bank social safeguard policies - a conditionality of GEF funding (C.A.P.E., 2003). The RPF/PF sets out quite stringent process and compensation standards in the event that the BMRP displaces people from land or productive resources. It explicitly covers farm workers and dwellers, and offers far greater protection than ESTA.

The planning domain of the BMRP covers a vast territory around the existing reserve cluster, but certain areas are prioritised. The western part of the Baviaanskloof is a major priority as it represents a 'hole' in the core of the reserve. The following discussion is focussed on this area.

\section{Farm dwellers: tenure rights and livelihoods in the Baviaanskloof}

\section{Mega-Reserve}

The BMRP is at a very early stage and any discussion of impact on farm dwellers is necessarily speculative. Concerted effort by the PMU since 2003 to build a dialogue with the community has gone some way to allaying mistrust and suspicions. It has been made abundantly clear that there will be no expropriation and that people will not be forced off the 
land. But there is scepticism about the 'biodiversity economy'. To appreciate the different perspectives, it is useful to disaggregate the community based on varying patterns of land ownership. Farm dwellers on private land face a different situation than those occupying land recently purchased by the state. A group of ex-farm dwellers now own a farm as a collective, under a land redistribution project. Other, mainly white landowners can be divided between those who depend on farming for their livelihood, and those who have recently purchased land for its naturebased tourism potential.

(i) Farm dwellers on state land

Coleske farm was bought by DEAET from a commercial farmer in 2001 and now serves as western gateway into the reserve. The farmer moved off the land, leaving behind a community of around 125 farm dwellers. He had employed 8 permanent workers and many others on seasonal basis. Many were born on the farm, have lived there their entire lives and numerous relatives are buried there. Initially, DEAET employed 45 people on temporary basis under a state-funded Poverty Relief project, raising the community's expectations of job-creation in the reserve. But there were problems in managing the workers. There were insufficient resources for supervision, and on occasion people were found playing dominoes at home during working hours. Relations soured between the reserve manager and the community. In 2004 the newly formed Eastern Cape Parks Board (ECPB) took over as statutory authority of the reserve. Poverty Relief funding ran dry and work stopped, virtually without notice. 
As the farm is now protected area, access to resources such as firewood, clay, honey, natural medicines and grazing has become severely restricted. "Die kampe is so klein, ons donkies is te swak om by die winkel uit te kom" (the designated grazing area is too small, our donkeys are underfed and too weak to reach the nearest shop). The farm store was closed down and people now walk over $30 \mathrm{~km}$ for basic supplies. Unemployment has made younger people dependent on the pensions of their elders. "Al die jong mense met vrouens en kinders het by ons ouens ingetrek" (the younger families have had to move in with us old folks). The community's continued existence has become increasingly precarious.

The PMU recognise that the Coleske case should trigger the Resettlement Policy Framework and Process Framework. People have lost jobs and access to natural resources. But moving the process forward is complicated by several factors. First, the ECPB - as management authority - has jurisdiction over resource access and utilisation in the reserve, so any agreements with the community require its consent. But the ECPB is very new and short on capacity. Second, there seems to be no consensus on whether the RPF/PF applies to Coleske. DEAET purchased the farm two years before the BMRP officially started, and some feel that DEAET should have handled any resettlement issues then under ESTA legislation. Instead the matter was left to linger and ECPB is reluctant to touch it. Meanwhile, there may well have been an influx of 'relatives' seeking employment or other benefits under a possible resettlement deal. To prove or disprove anyone's legitimate 'occupier' status today will require a very tricky process of forensic sociology. Third, the RPF/PF was drawn up by 
C.A.P.E. without involvement of Eastern Cape government, raising questions about 'buy-in' from those now responsible for the BMRP. Fourth, delivering on the promises of the RPF/PF is hugely complex. As GEF funds cannot be used for implementing action plans arising from the policy, it requires budgetary commitments and synchronised planning from a multiplicity of government institutions at local and provincial level. For example, in addition to alternative land and accommodation, RPF/PF provides for alternative employment, training and "measures to guarantee that livelihoods do not decline" - all equivalent to and preferably better than before (C.A.P.E., 2003:38-39). The RPF/PF process may be too institutionally complex to be viable, especially in the Eastern Cape where local government has been widely criticised for insufficient capacity and poor delivery.

While the PMU struggles to initiate the RPF/PF process and line up the various institutional actors, anger and frustration in the community is beginning to boil over. "Hulle het ons gesê da gaan altyd werk wees, maar die beloftes het verbreek" (they told us there would always be work, but the promises have been broken). Much is at stake - not just the fate of dozens of poor and vulnerable people, but the credibility of the BMRP itself and its approach to conservation. Across the Baviaanskloof coloured community, Coleske farm is now a constant reference point as to why conservation is bad for farm dwellers. As long as the Coleske case is not resolved in a way that is perceived as fair and just, the BMRP's stated philosophy of 'keeping people on the land in living landscapes' is seriously undermined. 


\section{(ii) Farm dwellers on private land}

Farm dwellers on private land have not yet felt the impact of the $\mathrm{BMRP}-$ it is too early to observe concrete changes in land use as a direct result of the project. Change for them will depend on whether or not landowners agree to alter the way they use their land to accommodate conservation concerns. This is driven strictly by economic considerations.

Among other things, the PMU would like to see farmers withdraw livestock from degraded mountain sides and concentrate farming in the valley bottom. ${ }^{7}$ Restoration of wilderness would attract greater numbers of tourists, creating new income streams. For farmers, such a shift involves two types of risk. One is reduced income from reduced stock levels in the short term, against uncertain growth of a biodiversity economy in a more distant timeframe. Second, the current practice of extensive mixed stock farming enables them to spread their risk, while shifting to intensive single stock farming increases risk. Landowners whose livelihoods depend solely on farm income are unlikely to volunteer for such a scheme without income-replacement guarantees ("Daar moet 'n waarborg wees"). If such guarantees were forthcoming (which seems unlikely) farmers could focus on a single stock type such as ostrich and cultivate land for animal fodder in the valley near the river, thereby enabling the surrender of significant land areas to biodiversity conservation and expanded tourist facilities. Another view is that such a scenario is inevitable. "We have to change our mindset, and fence ourselves in.” As new landowners with an eye on ecotourism withdraw grazing areas from agriculture, nature is encroaching 
on farms and winning the battle slowly but surely: wild animals are increasing and predators moving in. Farmers may be forced to concentrate their crops and stock in central fenced-in areas in order to protect them. ${ }^{8}$

Whichever the case, most farmers interviewed expect neither positive or negative impact on labour and tenure rights of farm dwellers. Jobs lost from herd reductions would be few and could probably be replaced by alternative work, such as servicing camp sites, trail guides, horse treks, etc. Nor do they see much room for job growth. Farm workers themselves see it differently. Those interviewed consistently expressed concern that a reduction in farm activity will place their jobs at risk, pointing at Sandvlakte farm as an example. The owner of Sandvlakte stopped farming some years ago to focus on ecotourism, leaving many farm dwellers without work, especially women. Those living on farms cannot see how they could possibly benefit from tourism enterprise on land belonging to someone else. "Ons bly op wit-man se grond" (we live on white man's land). Anything they do is by the grace of "die baas" (the master) - investment is a risk as permission can always be withdrawn. Who is going to put up infrastructure for a kiosk? Selling vegetables to tourists may be an opportunity, but a farm worker who fails to make him/herself available "om in te val" (to substitute) on Saturdays or Sundays risks termination because he is too inflexible. Everywhere, farm dwellers worry about their fate should the landowner decide to sell his farm to Nature Conservation - Coleske farm serves as a constant reminder.

\section{(iii) Ex-farm dwellers at Sewefontein farm}


Sewefontein is a land redistribution project. In 2001, a group of 75 landless people from the Baviaanskloof pooled their government housing grants to purchase the farm. Given the limited number of houses, the majority of shareholders do not reside there. Some live at Coleske while others live and work on other farms in the valley. Most intend to settle at Sewefontein at some point, when they get ill, old or for one reason or another can no longer remain where they presently are. Sewefontein is their 'insurance policy' against the ever-present threat of eviction. (Interestingly, other landowners in the Baviaanskloof view the Sewefontein trust as their own insurance against land expropriation for nature conservation. $)^{9}$ First and foremost, it offers them a secure place to live when they run out of options elsewhere; second is the possibility of generating some income. The latter is invariably associated with keeping livestock. For poor people livestock is crucial ("die hoofdoel op 'n plaas"). If someone has a quick debt to settle he can immediately sell off an animal - the easiest and quickest way to convert a farm product into cash. Equally, they find it inconceivable to confine their livestock to the current camps - grazing and browsing in the hills is necessary from time to time when the camps do not provide enough forage. It is particularly in this regard that the Sewefontein community feels threatened by the BMRP's conservation agenda. They worry about losing their hard-earned right to decide how to use their land (“Ons vrye reg gaan bekrimp raak") and being squeezed out by nature conservation as the wilderness encroaches on them and their animals. "Hulle vernou ons; ons bergwêreld 
word verkoop of uitgehuur; ons veeplekke raak beknoppig" (our mountains are being sold or rented; our grazing becomes limited).

The BMRP sees Sewefontein as an important opportunity to demonstrate how poor people can turn the biodiversity economy to their advantage. The farm itself holds considerable potential for ecotourism: stunning springs, space for a wilderness campsite, buildings suitable for conversion to guest houses. There is ample water to support intensive irrigated agriculture on smaller land areas. But before any of this can happen, the Sewefontein people have more basic problems to resolve. Like many land redistribution projects (Hall, 2004b), the large number of shareholders is the source of problematic group dynamics and continuous conflict over issues such as farm management, payment of wages to members working the farm, and who is entitled to live in the existing houses. There is general agreement that the group's size must reduce before any progress can be made in making Sewefontein a viable enterprise, and the PMU has agreed to take a back seat while a process of restructuring gets underway. ${ }^{10}$

\section{DiscuSSION AND CONCLUSIONS}

The early stage of implementation of the BMRP makes this concluding discussion more speculative than evaluative. The project is only two years into a twenty-year process. In addition, the plight of farm dwellers is set against a backdrop where many agricultural jobs have been and continue to be lost as a result of wider forces in the agricultural economy unrelated to the conservation agenda now being pursued. 
Nevertheless, the findings presented here point to some systemic and structural issues that reflect tensions in the BMRP's attempts to reconcile biodiversity conservation with land tenure rights and livelihoods of poor people, especially farm workers and dwellers.

First is the issue of land acquisition by the state as one element in the mega-reserve's expansion strategy. Where this directly results in cessation of agricultural activity as on Coleske farm, and also Nuwekloof farm where 5 workers lost their jobs in 2003, it introduces the possibility of loss of livelihoods and increased impoverishment of farm dwellers occupying that land. Although purchase of this kind is intended to form only a small part of the overall land consolidation and expansion strategy, it is presently the most visible and with visibly negative consequences. This creates a major image problem for the BMRP and its underlying philosophy that conservation be achieved in a manner that is embraced by local communities. Public perceptions are vital to this new approach to conservation. Cases like Coleske and Nuwekloof threaten to undermine its essence by fuelling suspicions that biodiversity conservation leaves poor and landless people worse off.

Second and closely linked to the above, social safeguard policies especially designed to protect poor people against these risks are proving very difficult to implement, for reasons mainly to do with institutional complexity and capacity. Moreover, the fact that neither the community nor the majority of the BSC appear to know about the existence of these policies raises questions about openness and transparency. The RPF/PF is arguably the most important policy instrument spelling out the rights of 
people affected by expansion of the mega-reserve. As long as people at both ends of the power spectrum - the poor whose rights the RPF/PF is designed to protect, and the steering committee responsible for overseeing the project - remain unaware their ability to realise these rights is seriously undermined.

Third, while early speculations suggest that farm dwellers on privately owned farms may not suffer the negative consequences experienced by their compatriots mentioned above, it is equally hard to see how they might actually benefit from a new biodiversity economy given the unequal power relations on farms. To overcome this, deeply entrenched attitudes and prejudices on both sides must be addressed. As pointed out by Du Toit (1996), social relationships on many of South Africa's farms are highly exploitative and unequal, but their persistence cannot be explained simply in terms of farmers' control - it rests also in some measure on farm dwellers' consent. Given their spatial isolation, they generally lack role models within their community to inspire them to pursue new opportunities. Questions that should be asked are: Who stands to benefit most? How can a social environment be created where farm dwellers can negotiate economic opportunities with their landowners on a more even-handed basis? What is required to create some visible success stories to demonstrate that the possibility of change for them exists? This will not happen by itself, and conservation agencies tend to lack the requisite skills. There is need for dedicated capacity to drive this agenda, for example a micro-enterprise development professional with a community development perspective, based in the area and tasked with 
identifying and developing a number of projects that respond to this urgent need.

Finally, questions must be raised about the increasingly popular and perhaps overstated belief that ecotourism can meet the challenge of reconciling biodiversity conservation, rural livelihoods and land rights. Although ecotourism is not the only element of the biodiversity economy being promoted by the BMRP, it appears to take centre stage. But stories of successful ecotourism ventures that involve poor rural people are scarce in southern Africa (Kepe et al., 2005). And as Magome and Murombedzi (2003) have pointed out, ecotourism has not yet been proven to yield significant benefits for poor people in land reform projects. For the Sewefontein community, ecotourism should be seen as only one livelihood possibility among many available to them. It may contribute to farm income without being the major focus of income-generating activities. Government and conservation agencies should aim to provide support that can enhance multiple livelihood strategies.

The BMRP has a difficult route ahead but it is one deserving of support. The broader bioregional strategy for conservation that looks beyond formal protected areas in terms of planning, conservation and economic development is a positive response to much of the criticism that has been levelled against conservation in the past (Kepe et al., 2005). Addressing the immediate and long-term needs of the poor, while simultaneously conserving South Africa's unique biodiversity is a huge challenge, and the BMRP has embraced it. The Baviaanskloof MegaReserve will be an interesting space to watch in the coming years. 
${ }^{1}$ The Cape Floral Kingdom is the smallest of the world's six floral kingdoms, and the only one entirely confined to one country. It is recognised as a global biodiversity asset.

${ }^{2}$ The term 'mega' is used because the area must be large enough to accommodate animal movements and gene flow over large distances, as well as encompass a gradient of habitat types.

${ }^{3}$ C.A.P.E. is a multi-stakeholder initiative between government, civil society and the private sector to coordinate and maximize efforts to conserve the Cape Floral Kingdom. The programme is backed by significant international funding from the Global Environment Facility (GEF) through the World Bank and the United Nations Development Programme.

${ }^{4}$ The market-based principles of South Africa's land reform programme have come under sustained criticism. At a national Land Summit in July 2005, the government announced its intention to review its market-based approach to land reform.

${ }^{5}$ The concept of a biodiversity economy is one where local economic development does not harm biodiversity, and where biodiversity resources are developed into economic opportunities.

${ }^{6}$ The PMU operates under a sub-contract to the Wilderness Foundation, an Eastern Capebased NGO.

${ }^{7}$ Interviews with Matthew Norval, Project Manager, and Andrew Skowno, Conservation Planner (PMU), August 2005.

${ }^{8}$ Interview with Thys Cilliers, August 2005.

${ }^{9}$ Interviews with: Skillie Rautenbach, Department of Agriculture, July 2005; and Chris Lamprecht, Chairman Baviaanskloof Farmers Association, August 2005.

${ }^{10}$ To this end, a Steering Committee has been formed involving inter alia Trust officials, Department of Agriculture, Department of Land Affairs, Southern Cape Land Committee. 


\section{REFERENCES}

Baviaanskloof Mega-Reserve Project (BMRP), 2004a. Conservation Strategy 2004-2007 (Third Draft).

http://www.wildernessfoundation.co.za/project/content.asp?PageID=266 [9 September 2005].

Baviaanskloof Mega-Reserve Project (BMRP), 2004b. Baviaanskloof MegaReserve Land Consolidation and Expansion Strategy: 2004-2006. BMR Project Management Unit Working Document.

Beinart, W. and Dubow, S. (Eds.), 1995. Segregation and Apartheid in Twentieth Century South Africa. London, Routledge.

Bernstein, H., 1996. South Africa's Agrarian Question: Extreme and Exceptional? Journal of Peasant Studies 23 (2-3).

Boshoff, A.F., 2005. The Baviaanskloof Mega-Reserve: An environmentally, socially and economically sustainable conservation and development initiative. Terrestrial Ecology Research Unit Report No. 52. Port Elizabeth, Nelson Mandela Metropolitan University.

Boshoff, A.F., Cowling, R.M. and Kerley, G.I.H., 2000. The Baviaanskloof Conservation Area - a conservation and tourism development priority. Terrestrial Ecology Research Unit Report No. 27. Port Elizabeth, Nelson Mandela Metropolitan University.

Brockington, D. and Schmidt-Soltau, K., 2004. The social and environmental impacts of wilderness and development. Oryx 38(2), 140-142.

Cape Action for People and the Environment (C.A.P.E.), 2000. A Biodiversity Strategy and Action Plan for the Cape Floral Kingdom. Cape Town, WWF South Africa.

Cape Action for People and the Environment (C.A.P.E.), 2003. Resettlement Policy Framework and Process Framework for C.A.P.E. Cape Town, NBI.

Centre for Rural Legal Studies (CRLS), 2003. Land Reform Options for Farm Workers: The uptake and impact of these on rural communities in the Western Cape. Stellenbosch, CRLS.

Clark D., 1998. Greater Baviaanskoof Wilderness Area: A regional development proposal -Rationalisation and consolidation of the western sector.

Executive summary. Department of Economic Affairs, Environment and Tourism, Eastern Cape Province.

Daily, G., 1999. Developing a Scientific Basis for Managing Earth's Life Support Systems. Conservation Ecology, 3, 2:14. http://www.consecol.org/vol13/iss2/art14, [19 June 2003].

Daly, E.H., 1996. Beyond Growth. Boston, Beacon Press.

Department of Environmental Affairs and Tourism (DEAT), 2003. Speech by the Minister of Environmental Affairs and Tourism, Mohammed Valli Moosa, on the Protected Areas Bill - National Assembly. 22 September 2003. http://www.environment.gov.za [28 October 2005].

Department of Land Affairs (DLA), 1997. The White Paper on South African Land Policy. http://www.polity.org.za/govdocs/white_papers/landwp.html [6 April 2005].

Delius, P., 1983. The Land Belongs to Us: the Pedi Polity, the Boers and the British in the Nineteenth Century Transvaal. Johannesburg, Ravan Press.

De Villiers, B., 1999. Land Claims \& National Parks: The Makuleke Experience. Pretoria, HSRC Publications.

Diamond, J., 1997. Guns, Germs and Steel: The Fates of Human Societies. New York, Norton \& Company. 
Du Toit A., 1996. The fruits of modernity: Law, power and paternalism on Western Cape farms. Programme for Land and Agrarian Studies Occasional Paper No. 3. Cape Town, UWC.

Elphick, R. and Malherbe, V.C., 1989. The Khoisan to 1828. In: Elphick, R. and Giliomee, H. (Eds.), The Shaping of South African Society, 1652-1840.

Cape Town, Longman Penguin SA, pp. 3-65.

Global Environment Fund (GEF), 2004. C.A.P.E. Biodiversity Conservation and Sustainable Development Project Document.

Hall, R., 2003. Farm tenure. Programme for Land and Agrarian Studies (Evaluating Land and Agrarian Reform in South Africa occasional paper series, No. 3). Cape Town, UWC.

Hall, R., 2004a. Land and agrarian reform in South Africa: A status report 2004. Programme for Land and Agrarian Studies Research Report no. 20. Cape Town, UWC.

Hall, R., 2004b. A Political Economy of Land Reform in South Africa. Review of African Political Economy, No. 100, 213-227.

Kepe, T., 2004. Land Restitution and Biodiversity Conservation in South Africa: The Case of Mkambati, Eastern Cape Province. Canadian Journal of African Studies 38(3), 688-704.

Kepe, T., Wynberg, R. and Ellis, W., 2005. Land Reform and Biodiversity Conservation in South Africa: complementary or in conflict? International Journal of Biodiversity Science and Management 1(1), 3-16.

Lahiff, E., 2003. The Politics of Land Reform in Southern Africa. Sustainable Livelihoods in Southern Africa Research Paper No. 19. Brighton, Institute of Development Studies.

Magome, H and Murombedzi, J., 2003. Sharing South African National Parks: Community Land and Conservation in a Democratic South Africa. In: Adams, W.M. and Mulligan, M. (Eds.), Decolonizing Nature. Strategies for Conservation in a Post-Colonial Era. London, Earthscan.

Mebratu, D., 1998. Sustainability and Sustainable Development: Historical and Conceptual Review. Environment Impact Assessment Review, No. 18, pp 493-520.

Millenium Ecosystem Assessment (MA), 2005. Living Beyond Our Means: Natural Assets and Human Well-being. Statement from the Millenium Ecosystem Assessment Board. http://www.maweb.org/en/products.aspx [30 October 2005]

Murray, M., 1995. The Value of Biodiversity. In: Kirkby, J., O'Keefe, P., and Timberlake, L. (Eds.), Sustainable Development. London, Earthscan.

Myers, N., Mittermeier, R.A., Mittermeier, C.G., da Fonseca, G.A.B. and Kent, J., 2000. Biodiversity Hotspots for Conservation Priorities. Nature, Vol. 403, 24 February 2000.

Pierce, S.M., Cowling, R.M., Sandwith, T. and Mackinnon, K. (Eds.), 2000. Mainstreaming Biodiversity in Development: Case Studies from South Africa. Washington, D.C., The World Bank.

Platzky, L. and Walker, C., 1985. The Surplus People: Forced Removals in South Africa. Johannesburg, Ravan Press.

Pretty, J.N., 1995. Regenerating Agriculture: Policies and Practice for Sustainability and Self-Reliance. London, Earthscan.

Quan, J., 2000. Land Tenure, Economic Growth and Poverty in Sub-Saharan Africa. In: Toulmin, C. and Quan, J.F. (Eds.), Evolving Land Rights, policy and tenure in Africa. London, DFID/IIED/NRI, pp.123-134.

Republic of South Africa (RSA), 1996. Constitution of the Republic of South Africa, No. 108 of 1996. Cape Town, Government Gazette No. 17678.

Republic of South Africa (RSA), 1998. National Environmental Management Act, No. 107 of 1998. Cape Town, Government Gazette No. 19519. 
Republic of South Africa (RSA), 2004. National Environment Management: Biodiversity Act No. 10 of 2004. Cape Town, Government Gazette No. 26436.

Roe, D. and Elliott, J., 2004. Poverty reduction and biodiversity conservation: rebuilding the bridges. Oryx 38(2), 137-139.

Roodt, M.J., 2003. Baviaanskloof community audit and attitudinal survey towards the establishment of a mega-reserve. Report prepared for the Wilderness Foundation. Grahamstown, Rhodes University.

Sachs, W., 1999. Planet Dialectics. London, Zed Books.

Sanderson, S.E. and Redford, K.H., 2004. The defence of conservation is not an attack on the poor. Oryx 38(2), 146-147.

Sandwith, T., 2002. Introduction. In: Pierce, S.M., Cowling, R.M., Sandwith, T. and Mackinnon, K. (Eds.), Mainstreaming Biodiversity in Development: Case Studies from South Africa. Washington, D.C., The World Bank, pp.1-4.

Statistics South Africa (SSA) and United Nations Development Programme (UNDP), 2003. Social Development Indicators for the Government of South Africa's 10-Year Review: Millennium Development Goals. Pretoria, SSA and UNDP.

Steiner, A., Kimball, L.A. and Scanlon, J., 2003. Global governance for the environment and the role of Multilateral Environmental Agreements in conservation. Oryx 37(2), 227-237.

Wegerif, M. and Russell, B., 2005. National Evictions Survey. Briefing to Parliamentary Portfolio Committee for Agriculture and Land Affairs, 30 August 2005. Nkuzi Development Association and Social Surveys.

World Commission on Environment and Development (WCED), 1987. Our Common Future. Oxford, Oxford University Press.

World Resources Institute (WRI), 2001. World Resources 2000-2001. Oxford, Elsevier Science Ltd.

Wynberg, R., 2002. A decade of biodiversity conservation and use in South Africa: tracking progress from the Rio Earth Summit to the Johannesburg World Summit on Sustainable Development. South African Journal of Science 98, May/June 2002, 233-243. 
Figure 1: Baviaanskloof Mega-Reserve

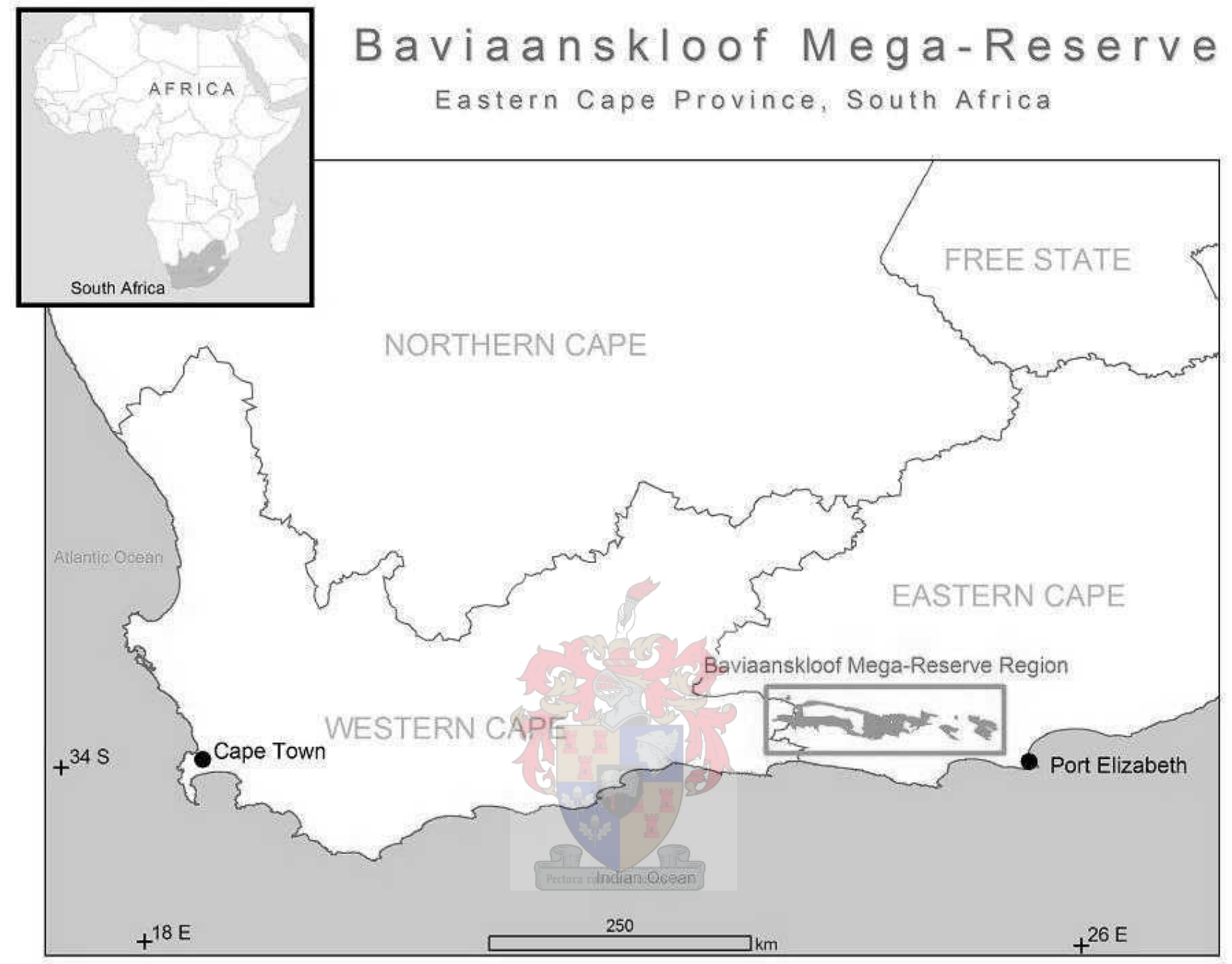

